
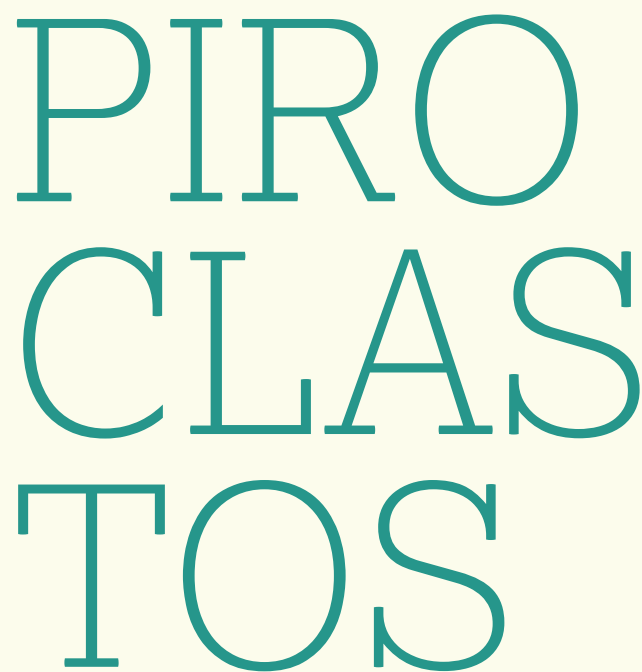

Do grego piro + klastós, -é, -ón.

Fragmentos de fogo expelidos durante a erupção e que solidificam. 



\section{ENSAIO POR UMA AULA ESTRANHA; OU SOBRE LITERATURA E PALAVRA.}

- DANIEL GLAYDSON RIBEIRO

[...] D'un côte, la jouissance est marquée par ce trou qui ne lui lasse pas d'autre voie que celle de la jouissance phallique. De l'autre côte, quelque chose peut-il s'atteindre qui nous dirait comment ce qui jusqu'ici n'est que faille, béance dans la jouissance, serait réalisé?

C'est ce qui, chose singulière, ne peut être suggéré que par des aperçus très étranges. Étrange est un mot qui peut se décomposer — l'être-ange [...]

LACAN (Semináire XX: Encore)

C

onta a testemunha - quase titulada em Filosofia, mas que desistiu pouco antes de concluir, a fim de transferir-se para o curso de Audiovisual - que em certa aula, durante uma greve geral, o professor, no caso o grande especialista (e tradutor) de Hegel na Faculdade, chegou à sala com um olho muito roxo, potencialmente esmurrado; e aquela aula deveria ser sobre Rousseau, mas ele, com seus modos de colono alemão, desatou a falar em Empfindung, Geschichte, Ideelle, Einbildungen... Neste momento, um corajoso aluno levantou-se (corpo / voz) e disse:

— Sr. Professor, eu li o texto e não é nada disso.

O hegeliano, assustado:

- Como não?... - e houve um incomensurável silêncio, durante o qual aquele aluno, agora consciente dos riscos que corria se empreendesse, mais além, explicar-se ou explicar Rousseau, manteve-se calado; ora, o catedrático, num acesso de honestidade e bravura, atinou: - Vamos ao texto!

Pedaços de madeira se chocaram com outras tábuas; abriram-se. 
Rente ao texto, feita a leitura em voz alta, publicamente constatada a razão do aluno, ainda pôde dizer:

— O que vocês queriam?! — obviamente não esperou por quaisquer respostas, e com a idêntica postura de seu mestre quando decretara a morte da Arte, esquartejada e ultrapassada pela Filosofia Ideal, ele atirou: - A Didática está morta!

A aula pode ser citada num texto acadêmico? Ou ela não tem legitimidade para tanto?

(Falo da simples e cotidiana aula brasileira, texto essencialmente oral e confuso; não a aula francesa, texto escrito, por vezes mais publicável que escutável -e é por isso que Barthes fala da aula como espaço criado para que um possa falar muito sem ter que escutar-; nem aquela legendária aula alemã do século XIX, prestes a virar livro a partir das notas, não menos confusas, dos alunos. Como se vê, a confusão a todos atravessa.)

Esquecidas por ora todas as tecnologias modernas da gravação, da reprodutibilidade técnica —e conseqüentemente: do controle—, quem poderá comprovar que o professor disse realmente o que eu afirmo como tendo sido (ou como tendo saído de) sua voz, numa aula? Uma proposta de solução seria o cotejo com notas de aula de outros alunos (mas logo imagino que isto não resolveria, pois cada ser se apropria como bem quer dos ditos alheios); outra proposta seria a oitiva do professor, quem, no entanto, poderia reconsiderar o que falou / dizer que estava apenas citando $\mathrm{x}$ e inclusive discordando de $\mathrm{x} /$ ou não lembrar do que falou / ou deliberadamente mudar de idéia, repensar, desmentir-se.

(É sábio reprová-lo por isso? / Mais sábio é mudar de idéia, às vezes)

Outrora, num curso sobre "Literatura e História na América Latina”, na aula sobre Vanguardas, perguntei, interessado na teorização do ministrante, se ele já havia publicado aquilo, e onde. Algo insultado, ele respondeu que é preciso pensar muito antes de publicar.

Do que concluo, satisfeito, que não é preciso pensar muito antes de proferir algo numa aula: abertura ao pensamento imediato, e ao devaneio mediato.

No primeiro encontro do curso intitulado "Do Sofrimento: Questões de Literatura e de Ética", Marcos Piason Natali afirma que o ensino da 
[1] "Nós", aqui, esvaziado da pretensão de verdade coletivamente corroborada, refere-se apenas ao(s) leitor(es) e eu(s) - e estes três parênteses de agora são apenas a esperança da multiplicação, ou da comunidade. literatura é algo estranho; ou, mais exatamente, que habitamos "estranhas instituições formadas para ensinar a leitura".

Necessito, impreciso, perguntar: diante de que estranheza nos sentamos?

Foi por esta palavra - estranho- que traduziram o Unheimliche freudiano. E, incomum dizer: suponho que haja mais sinonímia entre estes longínquos termos do que estamos ${ }^{1}$, geralmente, dispostos a aceitar.

De um modo geral, Jentsch não foi além dessa relação do estranho com o novo e não familiar. Ele atribui o fator essencial na origem do sentimento de estranheza à incerteza intelectual; de maneira que o estranho seria sempre algo que não se sabe como abordar. Quanto mais orientada a pessoa está, no seu ambiente, menos prontamente terá a impressão de algo estranho em relação aos objetos e eventos nesse ambiente. (1976, p. 277) (grafei)

Freud pretende ir além da "literatura médico-psicológica" ao demonstrar que "o estranho é aquela categoria do assustador que remete ao que é conhecido, de velho, e há muito familiar” (1976, p. 276, 277). Sua constatação parte de casos clínicos e vem a ser confirmada pelo uso lingüístico; antes, por uma atenção diferenciada do mais singelo procedimento morfológico: Un-heimliche, sendo heimliche (doméstico), heimsch (nativo), e un a partícula de negação, de oposição, ou, aí diz Freud, de repressão.

A 'negação' e a 'oposição' mantêm no ar aquilo que contradizem; todavia, falar em 'repressão' deixa ainda mais claro(a) a permanência do que se nega.

O psicanalista inicia um cotejo com outras línguas, mas logo desiste e volta ao alemão, que ele, aliás, também considera uma língua estrangeira. Em sua pesquisa pelo léxico, sobretudo o dicionário de Daniel Sanders de 1860, ele encontra uma definição retirada de Schelling, em meio a outros exemplos mui curiosos (e também advindos da Literatura, ainda que os nomes dos autores não tenham sido revelados).

\footnotetext{
... 'Unheimliche e imóvel como uma imagem de pedra.' 'Uma névoa unheimliche chamada nevoeiro da colina.' 'Esses jovens pálidos são unheimliche e estão tramando Deus sabe que desordem.' ' "Unheimliche" é o nome de tudo que deveria ter permanecido... secreto e oculto mas veio à luz' (Schelling) - 'Encobrir o divino, cercá-lo de uma certa Unheimlichekeit.' (apud Freud, 1976, p. 281)
} 
Notemos, de início, como o dito filosófico/literário, sobretudo o de autoria expressa, passa a integrar, tão natural quanto desconcertadamente, o léxico —e, de imediato, passa a complicar o já não tão fácil sentido-. Por que ele, o estranho, deveria ter permanecido oculto? Por uma obrigação moral? Ou identitária (a fim de preservá-la)?

Quem joga com esse caráter secreto, obscuro, não é Aquele que detém a luz na qual o estranho, afinal, e sempre, irrompe?

Enquanto que o significado I de heimliche é: "pertencente à casa, não estranho, familiar, doméstico, íntimo, amistoso, etc."; o significado II que o dicionário de 1860 ensina é: "escondido, oculto da vista, de modo que os outros não consigam saber, sonegado aos outros". As fronteiras conflituosas entre um significado e o outro, entre o Um e o Outro, interessam sobremaneira a Freud: "entre os seus diferentes matizes de significado a palavra 'heimliche' exibe um que é idêntico ao seu oposto, 'unheimliche'" (1976, p. 279, 280, 282). \{Idêntico ao oposto? Um conservador diria que essa palavra é exatamente o que se pode chamar de equí-voco\}. Trata-se da confusa proximidade que o significado II apresenta com relação à palavra oposta, isto é, à versão acrescida da partícula repressora. $\mathrm{O}$ caso é ilustrado com outra intromissão literária/ filosófica ao léxico, ora da pena menos canônica de Karl Gutzkow. E o dicionário é taxativo em condenar tal forma de cizânia.

Cf: “"Os Zecks [nome de família] são todos 'heimlich'.” (no sentido II) “'Heimlich'? O que você entende por 'heimlich'?” "Bem,... são como uma fonte enterrada ou um açude seco. Não se pode passar por ali sem ter sempre a sensação de que a água vai brotar de novo." "Oh, nós chamamos a isso 'unheimlich'; vocês chamam 'heimlich'. Bem, o que faz você pensar que há algo secreto e suspeitoso acerca dessa família?”' (Gutzkow). (1976, p. 280)

Início do décimo segundo capítulo da Lavoura arcaica: "(...e é enxergando os utensílios, e mais o vestuário da família, que escuto as vozes difusas perdidas naquele fosso, sem me surpreender contudo com a água transparente que ainda brota lá do fundo;" (1975, p. 72).

Cessa algo da contradição entre os significados I e II se entendo a casa como um esconderijo, ou o próprio estabelecimento da família como uma sonegação da comunidade? Cessa se acredito na segunda postulação da psicanálise, da qual, por conseguinte, há algo secreto e suspeitoso acerca de qualquer família? Isto se considero, ingenuamente, que o primeiro postulado psicanalítico é o da simbologia desejosa e recalcada do sonho; e o segundo, então, o da sexualidade latente da 
criança e o papel ativo e passivo do pai e da mãe nesse romance familiar, e estranho. $O$ segredo e a suspeita, pergunto quase outra vez, são da ordem da moral?

A Constituição de 1988 desta Nação, cujo nome vem da brasa, estabelece, nos incisos X e XI do Art. 5ํㅡ, o seguinte:

X - são invioláveis a intimidade, a vida privada, a honra e a imagem das pessoas, assegurado o direito a indenização pelo dano material ou moral decorrente de sua violação;

XI - a casa é asilo inviolável do indivíduo, ninguém nela podendo penetrar sem consentimento do morador, salvo em caso de flagrante delito ou desastre, ou para prestar socorro, ou, durante o dia, por determinação judicial;

Atentem que, durante a noite, nem a "determinação judicial" vigora.

Em Freud, encontro já estabelecida - como generalidade - a concepção positivista de que o homem se encontra num "estádio de desenvolvimento" em que ultrapassou ou libertou-se das crenças animistas. Ora, são duas as categorias do estranho: primeira, quando "acontece realmente em nossas vidas algo que parece confirmar as velhas e rejeitadas crenças"; já a segunda "provém de complexos infantis reprimidos" (1976, p. 300, 308, 309). Enquanto a primeira categoria ocorre quando vem à luz algo "superado", a segunda acontece quando algo "reprimido" nos atinge, emerge.

Daí, se algo está efetivamente superado, como pode vir à luz, emergir? Interessa aqui a tênue fronteira entre superação e repressão. Por um instante, Freud chega a igualar os termos, mas logo se corrige; na seqüência do parágrafo, ele próprio admite a nebulosidade dessa distinção: "Quando consideramos que as crenças primitivas relacionam-se da forma mais íntima com os complexos infantis e, na verdade, baseiam-se neles, não nos surpreenderemos muito ao descobrir que a distinção é muitas vezes nebulosa" (1976, p. 310).

Ex-traño, exilado (ex-ilhado);

Te extraño, sinto tua falta, tenho saudades de ti;

Es-tranho, o que está fora das En-tranhas. Que saiu de Lá, mas que permanece Sangue do Mesmo Sangue.

“- Você diz coisas estranhas, meu filho." (Nassar, 1975, p. 153) 
"A literatura está em crise". "A poesia está em crise".

A Grécia está em crise.

Antonios Perris, músico e poeta grego, vítima aos 60 anos dos joguetes (anti-)econômicos entre seus dirigentes políticos e a Zona do Euro - euro! esta moeda recente que é um absurdo fracasso e, nada obstante, continua sendo mais cara que muitas "moedas fortes"...-, depois de ter vendido suas propriedades e chegar a não ter o que dar de comer à mãe, que sofria de Alzheimer e esquizofrenia, lança-se "ao espaço" desde o terraço do prédio em que moravam, cinco andares, de mãos dadas com ela, no dia 24 de maio do corrente ano de 2012, em Atenas, no bairro de Metaxourgeio.

Um dia antes, Antonios já havia se lançado "ao espaço": escrevera sua carta de suicídio, e a publicara num sítio de compartilhamento de textos. A tradução ao português é anônima:

[...] Não estou pedindo com a raiva ou o rancor que sentia por vocês ontem, pois a morte me liberou também disso. Se lhes peço, por favor, por dignidade, por respeito é porque é seu dever e podem fazê-lo. Sim, vocês podem. É muito simples. Há 350.000 famílias que foram despejadas em seu país desde que a crise começou a nos atormentar. Há milhares que estão sendo despejadas todo mês pelos mesmos bancos que vocês estão salvando com o dinheiro desses pobres que foram sacrificados durante anos e pagaram seus impostos. Agora essas pessoas nem isso podem fazer. São famílias sem trabalho, com crianças, com idosos, com enfermos. Façam por um momento esse esforço de imaginação, que sempre evitam, e pensem no que estão passando essas pessoas. Imaginem o que é ficar sem casa, ter medo e dormir sobressaltado por cada ruído que pode anunciar o despejo, a vergonha de que seus filhos vejam a polícia arrastando você para fora da sua casa, a vergonha de pedir asilo na casa de um amigo ou parente, que podem estar talvez tão sufocados como você e os seus, e o que é pior, a humilhação de dormir na rua ou em um albergue... Não é preciso muito esforço para sentir-se mal só de pensar.

Pois façam com eles o mesmo que fizeram com os bancos. Obriguem os bancos a suspenderem os despejos. Obriguem os bancos a perdoar as dívidas hipotecárias e devolverem as casas que tomaram. $\mathrm{E}$ obriguem os bancos a alojar milhares de famílias que necessitam em casas que estão vazias à espera de negócios. Estabeleçam um aluguel razoável, estudem cada caso mas arranjem uma moradia para todos. 


\begin{abstract}
Momentos de exceção como estes, exigem medidas de exceção como as que foram tomadas para resgatar os bancos. Resgatem as pessoas. Podem fazer isso porque o fizeram com os bancos. Foram salvos sem que lhes tenham imposto condições. Nacionalizaram a entidade que executa $80 \%$ das hipotecas, estão dispostos a dar-lhes o que necessitem e dizem que necessitam de 15 bilhões. Este banco é nosso, criem vocês suas próprias normas, salvem aos que necessitam. E façam isso logo. A vida de outros depende hoje de vocês.
\end{abstract}

Minha mãe já não era capaz de saber o que estava acontecendo. Mas vocês não têm Alzheimer, embora pareça algumas vezes que vocês esqueceram onde deixaram sua consciência. Em meu leito de descanso, cheguei a crer por um momento que a têm. Por isso me atrevi a escrever estas linhas que podem parecer ingênuas, porque estamos construindo um mundo em que defender a justiça parece coisa de inocentes. Deixem-me este último sonho antes de pegar no sono eterno. Estendam as mãos aos que estão a ponto de lançar-se ao espaço. Façam alguma coisa.... (2012) (como se ainda fosse preciso, grifei)

Subtraídos do sacrifício cotidiano do trabalho e dos impostos, parece restar-lhes, aos gregos, a mendicância — num lugar onde a ajuda real (não a macro-monetária) está interditada: os asilos não aceitaram a mãe do músico, de 90 anos, porque estava muito doente (!) — ou o suicídio. Segundo números não oficiais, duas mil e quinhentas pessoas se suicidaram na Grécia dos últimos três anos. A taxa de sacrifício, conceito da Macro-Economia, deixa de funcionar na relação desempregados/controle da inflação e passa a funcionar nesta outra: suicidas/ controle da fome.

Pelo pouco e mal que se lê através do emaranhado de notícias sobre a crise grega, as quais, tal como os dirigentes políticos destinatários da mensagem póstuma (na intenção do autor), preferem tratar de números a tratar de pessoas - lhes interessa o cálculo e não o existir -, a lúcida solução apontada por Antonios Perris não parece estar sequer em pauta. Affonso Romano de Sant'Anna, de viagem ao país em crise, escreve uma crônica em que também sugere uma "simples" solução: se o Ocidente pagasse os direitos autorais que deve aos gregos antigos (Sócrates, Sófocles, Homero - direitos por não ter escrito uma linha, no caso do primeiro e também quiçá do último...), tudo estaria resolvido. "Nós pagaremos, olímpica e dionisiacamente, para que eles simplesmente existam" (2012). A solução do cronista e poeta rico também não está em pauta. 
Diante do desprezo às soluções outrora apresentadas, este texto se exime de aventar outra, seja ela ingênua, sentimental ou político-econômica. Fazendo isto, estou sendo mais inútil que os dirigentes responsáveis?

- É impossível.

Mesmo assim, para não correr o risco de parecer tão inútil, segue uma proposta extemporânea: e se a Grécia tivesse declarado a moratória ao invés de submeter-se à negociação com os donos do dinheiro, negligenciando assim a suposta moral das finanças internacionais, não teria sido melhor? Não é melhor a pobreza comum do que a riqueza exilada nos escritórios de Londres ${ }^{2}$ ? Mas a pobreza comum também não está em pauta. A idéia da simples (sobre)vivência, da auto-organização "primitiva”, foi completamente desbaratada pelo horizonte capitalista?

Faltou quem fizesse a chacina dos falsos pretendentes. Na versão em inglês que circulou com a carta de Perris, não constam os três parágrafos que cito, e há versos em seu lugar. Eles propunham uma solução mais feroz:

\author{
We are governed by traitors \\ Bankers and loan sharks \\ And all their minions \\ R. So you have to hit them mercilessly \\ Without compassion, before you disappear \\ Otherwise you'll be living in misery \\ And in injustice forever \\ So, mercilessly and without compassion, \\ Until not one of them is left. (2012)
}

That's it! Na tradução para o português, lemos uma solução "humanizada"... (outros "humanos" acusariam: comunista!); já em inglês, lê-se a solução armada (ou seria apenas e infelizmente cinematográfica?). Sequer uma carta de suicídio mantém-se incólume ao circular pela imprensa internacional. Mas o suicídio requer muito mais: suicídio é um requerimento filológico. Uma querência post mortem?

A crise é tão intrínseca à literatura quanto o é ao capital?

A crise é tão intrínseca ao capital quanto o é à literatura?

A decisão quanto à sintaxe, a ordem mais apropriada para esta pergunta, passa já pela decisão, talvez indecidível, entre literatura e capital: qual dos dois é mais crisível? Crisível é aquilo que provoca crise. Não se trata de algo que vem a ser assaltado pela crise, como evento externo, mas algo que a elabora a partir de si mesmo, e que provavelmente mal pode existir sem ela.

[2] Da crônica de Romano de Sant'Anna: “[...] dizem que a Grécia tem 772 armadores, gente rica que controla o país. Mas o capital e escritórios deles estão em Londres." (2012) 
Numa tarde, a aluna exasperada ante a insistência com que falavam da crise atual da literatura menciona que, segundo sua professora de francês, desde meados de 1700, quando da Enciclopédia de Diderot e D'Alembert (e de outras dezenas de autores), a literatura já estava em crise.

— Que crise é essa tão sem fim?

Vamos ao texto: o verbete Littérature da Encyclopédie, ou Dictionnaire Raisonné des Sciences, des Arts et des Métiers, par une société de gens de lettres (1751-1772), escrito por Chevalier Louis de Jaucourt:

LITTÉRATURE, s. f. ( Sciences, Belles-Lettres, Antiq. ) terme général, qui désigne l'érudition, la connoissance des Belles-Lettres \& des matieres qui y ont rapport. Voyez le mot LETTRES, où en faisant leur éloge on a démontré leur intime union avec les Sciences proprement dites.

Il s'agit ici d'indiquer les causes de la décadence de la Littérature, dont le goût tombe tous les jours davantage, du moins dans notre nation, $\&$ assurément nous ne nous flattons pas d'y apporter aucun remede.

[...] le principal motif de telles gens, n'est que d'avilir le bien d'autrui, afin d'augmenter le prix du leur. Incapables de travailler, à s'instruire, ils ont blamé ou méprisé les savans qu'ils ne pouvoient imiter; \& par ce moyen, ils ont répandu dans la république des lettres, un goût frivole, qui ne tend qu'à la plonger dans l'ignorance $\&$ la barbarie.

Cependant malgré la critique amere des bouffons ignorans, nous osons assurer que les lettres peuvent seules polir l'esprit, perfectionner le goût, \& prêter des graces aux Sciences. Il faut même pour être profond dans la Littérature, abandonner les auteurs qui n'ont fait que l'effleurer $\&$ puiser dans les sources de l'antiquité, la connoissance de la religion, de la politique, du gouvernement, des lois, des moeurs, des coutumes, des cérémonies, des jeux, des fêtes, des sacrifices \& des spectacles de la Grece \& de Rome. Nous pouvons appliquer à ceux qui seront curieux de cette vaste $\&$ agréable érudition, ce que Plaute dit plaisamment dans le prologue des Ménechmes: « La scène est à Epidamne, ville de Macédoine; allez - y, Messieurs, \& demeurez - y tant que la piece durera ». (D. J.) (175..., p. 594-595)

Literatura aí não designa propriamente ou apenas um modo de escrita, mas um profundo conhecimento, tanto das Bellas-Letras quanto das Sciencias - a relação ainda era amigável —, e isto se chama(va) erudição. 
A conjuntura descrita no verbete remonta à famosa querela entre antigos e modernos que agitou o final do séc. XVII em França. A decadência - não exatamente a crise - delatada por De Jaucourt anuncia a vitória de Perrault e não de Boileau, já que detecta um movimento generalizado de negação, um desejo ardente de ultrapassar (superar), enfim, uma revolta contra a predominância ou a insistência da cultura greco-romana. O que para uns é decadência, para outros é revolução.

Por mais antiquado ou mesmo ridículo que possa parecer ao leitor moderno o definir a função da literatura assim: polir o espírito, aperfeiçoar o gosto e render graças às ciências; por mais fácil que seja dizer: o cavaleiro está falando de uma outra coisa que não a nossa literatura; eu ousaria perguntar se é absolutamente outra coisa a que ele se refere, ou seria, a bem da verdade, outro tempo da coisa. Isto é: a radicalidade da literatura moderna, esta que para Foucault inicia com Marquês de Sade, é suficiente para fundar outro nome - Literatura versus literatura, sendo esta letra minúscula o sinal de sua intensa revolta (contra a burguesia; contra a ciência e a religião; até certo ponto, contra a língua; enfim, contra o pai) — ou nesta fundação estão sempre os resquícios, as ruínas se se quiser, mas é melhor: o rastro (o rosto) Daquela?

Em Invenção de Orfeu, Canto Sétimo:

Sei dos pássaros, sei dos hipopótamos, sei de metais, de idades, aconteço-me, embebo-me na chuva que é do céu, abraso-me no fogo dos infernos.

Porquanto,

como conhecer as coisas senão sendo-as?

Abrigo as minhas musas, amam sôbre.

Aflijo-me por elas, sofro nelas, encarno-me em poesia, morro em cruz, cravo-me, ressuscito-me. Petrus sum. Sou Êle mas traindo-o, mas em burro, com êsses cascos na terra, e ventas no ar, cheirando Flora; minhas quatro patas rimam iguais, forradas, alforriadas, burro de Ramos, levo sôbre o dorso Alguém em flor, Alguém em dor, Alguém. 
burro épico, vertido pra crianças, transporto-as à outra margem, sou Cristóvão Colombo, sou columba, Deus Espírito que desce sôbre o início, sou palavra antes de mim, eu evo. Ave Maria, Eva sem culpa, tem de mim piedade, Pia sacramental de que emerjo ilha.

— Quid petis ab Ecclésia Dei?

$$
\text { - Fidem. }
$$

— Fides, quid tibi prœstat?

— Vitam æternam.

(De Lima, 1952, p. 266)

Por mais longe que andemos, inclusive (ou sobretudo) na revolução, sempre voltamos à eterna cena da origem. Espirais de afirmação, negação, inversão, reafirmação, desconstrução das paternidades. As preces e as sublevações. Os cantos e as paródias. Os anseios de superar a origem, quiçá apenas reprimindo-a. "Sou Êle mas traindo-o, mas em burro". Ou a vontade de assumi-la, fazendo-se necessário então (paradoxalmente?) descobri-la — inventá-la.

(A “crise atual da literatura" não está, à primeira vista, no embate pela determinação da origem. Ela é um pouco mais mundana. Duas são, basicamente, as lamentações: primeira, que seu espaço no mercado cultural (na cultura mercadológica) está há mais ou menos um século em plena decadência, suplantada pelo rádio, cinema, televisão, games e o que mais vier; segunda, que há livros demais, editoras em toda esquina, gente demais publicando, acreditando-se escritor, que há mesmo prêmios literários demais, concursos, editais, festivais.

Ao mesmo tempo em que tal discurso demonstra nostalgia por aquele tempo em que o livro era o locus-ápice da comunicação humana, evidencia também a sua vontade de voltar a ser restrita, para poucos, entre poucos. A queixa é duplamente anti-tecnológica: rebela-se tanto contra as novas tecnologias que produzem as últimas máquinas da comunicação, quanto com a popularização da velha tecnologia da imprensa.

Literatura \Capital \Democracia.

-A democracia está em crise; ou a democracia é a crise?-

Ora, se há poucos que lêem e muitos que publicam, uma "simples" solução seria que lêssemos Uns aos Outros.

Não ao cálculo / Sim ao existir.) 
Quando, fazenda antiga,

abrem-se as venezianas de um livro,

a teoria outrora lida

insurge como selva escura

como homemlmulher perdidalo

entre gigantescas árvores de aéreas raízes

e a leitura, comum, como um,

apenas trepa galhos,

se aninha na fronde,

colhe o pomo.

$[p o(e) m o(\varnothing a)]$

ambos, os perdidos e os atrepados,

permanecem

nanatureza.

Aula sobre a aporia da paternidade em Lavoura arcaica, um aluno se encoraja a criticar a estratégia do romance em tratar isoladamente uma família, "quando isto não existe mais, porque faz muito tempo que as famílias se encontram apenas uma ou duas vezes por ano, nas festas" / Não seria necessário precisar que o leitor, neste caso, já não fala do livro, mas de si mesmo: da sua condição ou sua contingência, em seu espaço e tempo, inclusive passíveis estes de serem demarcados, ainda que inadvertidamente, com as palavras: Cidade de São Paulo, Século XXI?

Inadvertidamente quer tanto dizer que, por um lado, o espaço e o tempo daquele aluno são conceitos-situações bem mais específicos(as) e até certo ponto insondáveis - a não ser que o investigássemos ou o inventássemos, mais e melhor, como um personagem; quanto, por outro, que a constatação sociológica por ele proferida não se limita, de fato, a esta Cidade e a este Século / Contudo, e isto me parece muito claro, ela não pode ser tomada como uma generalidade, capaz de desbaratar a "estratégia" do romance.

Nem dois meses de publicado, e o primeiro livro de Raduan Nassar já havia obtido, entre tantas outras exegeses, uma explicação alegórica: "Lavoura arcaica é também uma alegoria. A família é a figuração da sociedade. $\mathrm{O}$ circuito fechado da família patriarcal prefigura o circuito fechado da sociedade". Mais adiante: "São muitos os que trabalham sem 
[3] É muito discutível isso de onde está documentado o passado (no texto explícito ou no simbólico, ainda mais quando se trata de histórias escusas), mas deixemos passar pelo bem da -já tão fragmentada e louca- argumentação. apaziguar a fome. É tão enganosa a união da família como da sociedade" (1976). Aos olhos de Octavio Ianni, o romance é um manifesto ou um panfleto (nada de pejorativo aí, pelo contrário) em prol da liberdade individual: André representa a revolta contra o trabalho, esse castigo imposto pelo "pai-patriarca-patrão".

Fica explícita, mais na crítica do que no livro, a problemática ditatorial $^{3}$, o estado de coisas da política brasileira em 76, a cisão profunda entre o que se dizia e o que se fazia (entre o que se discursava de milagres brasileiros e o que se torturava e matava de modo profano). "Tanto a família como a sociedade poderiam romper-se se a palavra fosse livre". O texto de Ianni é forte; deixa falar seus devaneios (bem reais) que brotaram desde o livro, do qual ele recorta de forma taxativa o que interessa à sua análise. Assim, o sociólogo parece buscar na literatura a formulação menos técnica —no sentido da tecnocracia científica e para não dizer: mais lúdica ou mais sensível- que confirme ou ilustre os seus conceitos de trabalho, i.e., de pesquisa. (A pergunta angustiada do teórico da literatura: é possível, com qualquer outro método, fazer [trabalhar] diferente? E mais, ainda: como pode ser "tão enganosa a união da família", se no instante do suicídio ela salta de mãos dadas?). Volta à baila, num outro nível, mais tenso, aquele problema de já não falar do livro, mas de si.

Octávio lanni: Em Lavoura arcaica, o sermão do pai-patriarca-patrão é um belíssimo monólogo sobre o tempo, sobre a importância da duração da vida das coisas e das gentes: nascer, crescer, amadurecer, declinar, sucumbir, renascer. Mas o tempo, aqui, é uma metáfora do trabalho como duração, exorcismo, castigo e expiação. Gostaria que você comentasse esta colocação.

Raduan: A colocação me parece um pouco discutível quando se leva em conta aquele contexto familiar e sua irrecusável carga de afeto. Até mesmo um trabalho contratado e corriqueiro, dentro de limites, é um antídoto contra o marasmo do tempo, o que gratifica e, portanto, enfraquece o seu caráter de castigo e expiação. No caso em que se é sujeito e o trabalho é uma escolha, o bom trato com o tempo seria revertido em recompensas, tematizadas por sinal naquele sermão. Seja como for, não sei bem por onde transita aquela pregação. Só mesmo o modo de sentir de cada leitor. (1996, p. 30)

Raduan frustra claramente, ainda que com rodeios, a colocação de Ianni. Suas concepções são divergentes: que o trabalho possa ser "um antídoto contra o marasmo do tempo", definitivamente não era o que o 
arguto sociólogo esperava ou gostaria de receber como resposta. Faz sentido que ele tenha lido, da pena deste autor, o romance da revolta contra o trabalho e a família? A alegoria pode ser inconsciente? Ou ela precisa estar, de fato, apenas na consciência do leitor, do Outro?

Mas antes caberia duvidar desta minha estratégia de representar o conflito entre o crítico e a obra através de uma entrevista entre o crítico e o autor. Já nos aconselharam, pelo bem da autonomia da forma, a não dar razão ao que diz, fora do livro, Um autor sobre seu livro - mas então, pergunta (talvez) aporética: porque seria aconselhável ouvir o que diz Outro, fora do livro, sobre o livro do Um?

Senão pela latência de que este Outro seja Um.

Ao nativo, o Um, só é permitido falescrever literatura; ao estrangeiro, o pesquisador, o O., só é permitido falarlescrever ciência (ou teoria).

O problema da transgressão ${ }^{4}$.

$\{[(U n)]\}$-heimsch.

O problema de não voltar da viagem ao nativo.

O dilema de voltar nativo.

A querência.

( O filho pródigo )

\author{
A busca de uma língua franca \\ entre o Um e o Outro. \\ A viagem do Outro ao Um como entrega \\ [ a encomenda de si ], \\ detença de Um em Outro.
}

(Com o objetivo nobre de alcançar alguma espécie de totalidade dentro da gigantesca história literária, mesmo com os inacabáveis recortes: áreas, épocas, gêneros ou subgêneros a que cada curso se delimita, as aulas de literatura costumam fundamentar-se em calhamaços - no sentido moderno de: muitos e grossos livros. São propostos, de fato, dezenas e dezenas de obras por semestre [já tive aulas que exigiam a leitura de quatro romances mais alguma coisa da crítica, pr'essa semana]. Semelhante ao leitor sintético de Libertella, o estudante de Letras pica as veias com tinta de livro ${ }^{5}$.

Já não é possível o devaneio, senão o surto. A insônia do texto.

A estratégia de alguns cursos [sérios] de filosofia e mais raramente de sociologia, que não se envergonham ao deter-se, durante todo um semestre, em um livro ou mesmo alguns capítulos de um livro, com o
[4] Em Critique et vérité, início da seção " La crise du Commentaire": "Or voici que, par un mouvement complémentaire, le critique devient à son tour écrivain. Bien entendu, se vouloir écrivain n'est pas une prétention de statut, mais une intention d'être. Que nous importe s'il est plus glorieux d'être romancier, poète, essayiste ou chroniqueur? L'écrivain ne peut se définir em termes de rôle ou de valeur, mais seulement par une certaine conscience de parole. Est écrivain celui pour qui le langage fait problème, qui en éprouve la profondeur, non l'instrumentalité ou la beauté. Des livres critiques sont donc nés, s'offrant à la lecture selon les mêmes voies que l'ouvre proprement littéraire, bien que leurs auteurs ne soient, par statut, que des critiques, et non des écrivains. Si la critique nouvelle a quelque réalité, elle est là : non dans l'unité de ses méthodes, encore moins dans le snobisme qui, dit-on commodément, la soutient, mais dans la solitude de l'acte critique, affirmé désormais, loin des alibis de la science ou des institutions, comme un acte de pleine écriture. Autrefois séparés par le mythe usé du « superbe créateur et de l'humble serviteur, tous deux nécessaires, chacun à leur place, etc. ", l'écrivain et le critique se rejoignent dans la même condition difficile, face au même objet : le langage. / Cette dernière transgression, on la vu, est mal tolérée. [...]" (Barthes, 1966, p. 46-47).

[5] Para o futuro, lugar em que Libertella imagina este seu "leitor", já não será necessário o livro, nem as telas: bastará a tinta da caneta, nua e crua. Especificamente, a "lapicera Parker" (2006, p. 69). 
objetivo de apre(e)ndê-lo, está sem dúvida mais perto de estabelecer um discurso que fala do livro, e não de si. Este método retoma a sacralidade do texto, e carrega, quiçá por isto, o problema inverso. A forma demorada de aprendizagem de determinado livro ou autor é quase sempre dogmática. Busca-se a (utópica) compreensão puramente objetiva, com a exclusão mais completa possível do si mesmo, e inclusive da objetidade (a constante metamorfose da presença das coisas, de que fala Heidegger).

Qualquer devaneio será escorraçado pela razão. A vigília do texto.

Proponho retomar ou assumir - sim — a sacralidade [o que é estudar, analisar um texto, mesmo no caso da crítica negativa, senão consagrá-lo?]; deixando falar também — sim — o si.

Delongar-se no texto .......... lê-lo em voz alta, e em quantas línguas já estiver ..;... um poema, talvez mesmo um verso, uma página de romance, conto ou de ficção filosófica, talvez mesmo um parágrafo, será bastante para o devaneio de uma aula estranha ...!.... e será mola para que eu mesmo - professor e aluno[s] — se revele[m], numa comunidade para o Um e para o Outro, para a livre detença mútua.

O sono, o sono provisório do texto, ou ainda melhor, encore, o sonho do texto, el sueño del texto, para poder hablescribir la soñanza, falescrever do-livro-e-de-si, apto ante as duas profundidades, os Dois ou Um Só Abismo[s].)

" $E$ a grande Face descerá quando dormires e ficarás um ser estranho, / com cem órbitas cobrindo tua pele bruta;" (De Lima, 1974, p. 58).

N'O Livro de Jó, 4; 2, diz Elifaz, o temanita: "Se intentarmos falar-te, enfadar-te-ás? Mas quem poderá conter as palavras?".

A intensidade significativa da forma textual na filosofia atenta, em amplo espectro, contra a idéia da arbitrariedade do signo — não quanto ao signo-palavra/ signo-som ou signo-frase (quem contra isto atenta é a poesia), mas sim quanto ao signo-livro ou signo-discurso. O dialogismo quase sempre monológico de Platão. $\mathrm{O}$ excesso sistêmico de Hegel que, num instante aléphico, se torna a confusão densa do Prefácio-. A pulsão blasfematória de Nietzsche. As linguagens des-dobradas de Heidegger e de Derrida: no primeiro, a hifenização mágica, a inserção de símbolos sobre símbolos ("ser"), a criatividade etimológica; no segundo, o neologismo, a colagem e o recorte de ou a intromissão em palavras, o revolver-se inebriante sobre suas próprias formulações, a inserção da autobiografia, a escrita (im)possível de oralizar, o não-sei-quê. 
Em Derrida parecem coexistir, em aberto conflito, ironia e mística. Fazendo aqui a errada suposição (da totalidade) da obra, e fosse viável estruturá-la, penso num certo parênteses de La litterature au secret, Une filiation impossible, onde o escritor franco-argelino menciona os arcos-íris que surgiram ao final de sua viagem à Palestina e depois a Jerusalém. Arco-íris, luz \& água, refratada \& refletida, espectro de cores que anuncia, simboliza a Aliança: não haverá mais dilúvio. Segue uma singela proposta estrutural pro discurso inestruturável: "Je n’ai jamais trop cru [...] mais jê n'ai pas pu être insensible [...]". Isto não poderia servir — passez-moi la généralisation - tanto para a relação de Derrida com a filosofia e a teologia, quanto para sua relação com o judaísmo e com Deus?

(Na literatura, e apenas nela, ele acreditou piamente, a seu modo.)

[...] Le secret du météorite: il devient lumineux à entrer, comme on dit, dans l'atmosphère, venu on ne sait d'où - mais en tout cas d'un autre corps dont il se serait détaché. Puis ce qui est météorique doit être bref, rapide, passager. Furtif, c'est à dire, dans son passage éclair, peut-être aussi coupable et clandestin qu'un voleur. Aussi bref que notre phrase encore suspendue ( «Pardon de ne pas vouloir dire »). Question de temps. A la limite d'un instant. La vie d'une météorite aura toujours été trop courte: le temps d'un éclair, d'un coup de foudre, d'un arc-en-ciel. On dit que l'éclair de la foudre ou l'arc-en-ciel sont des météores. La pluie aussi. Il est facile de penser que Dieu, même le Dieu d'Abraham, nous parle météoriquement. Il descend sur nous à la verticale, comme la pluie, comme un météore. A moins qu'il ne descende en suspendant la descente, en interrompant le mouvement. Par exemple pour nous dire « Pardon de ne pas vouloir dire... ». Non que Dieu lui-même dise cela, ou se rétracte ainsi, mais c'est peut-être ce que veut dire pour nous « le nom de Dieu » . (Derrida, 1999, p. 185-186)

\section{Em Altazor o el viaje en paracaídas, no Prefacio:}

Aquél que oye durante la noche los martillos de los monederos falsos, que son solamente astrónomos activos.

Aquél que bebe el vaso caliente de la sabiduría después del diluvio obedeciendo a las palomas y que conoce la ruta de la fatiga, la estela hirviente que dejan los barcos.

Aquél que conoce los almacenes de recuerdos y de bellas estaciones olvidadas. 
Él, el pastor de aeroplanos, el conductor de las noches extraviadas y de los ponientes amaestrados hacia los polos únicos.

Su queja es semejante a una red parpadeante de aerolitos sin testigo.

El día se levanta en su corazón y él baja los párpados para hacer la noche del reposo agrícola.

Lava sus manos en la mirada de Dios, y peina su cabellera como la luz y la cosecha de esas flacas espigas de la lluvia satisfecha.

Los gritos se alejan como un rebaño sobre las lomas cuando las estrellas duermen después de una noche de trabajo continuo.

El hermoso cazador frente al bebedero celeste para los pájaros sin corazón.

Sé triste tal cual las gacelas ante el infinito y los meteoros, tal cual los desiertos sin mirajes.

Hasta la llegada de una boca hinchada de besos para la vendimia del destierro. (Huidobro, 1931, p. 13-14)

Perdão por não querer dizer? Mas a mensagem exata é esta, literalmente e em todos os sentidos, como escreve Rimbaud na carta à mãe. Assim como a mensagem exata de Abraão é o silêncio.

Perdão por não querer dizer? Trata-se de fato de ocultar um segredo que o escritor bem sabe, ou mais de intentar ardentemente (roçando - en effleurant - na pedra, no papel, na tela da máquina) desvelar um segredo que ele mal sabe? A (L)literatura quer dizer algo tão alto (por vezes no sentido do Altíssimo, por outras no do entorpecido), que aparenta - não por vontade de enganar, de esconder, mas pela incapacidade daquilo ser dito de outro modo - nem querer dizer, nem poder querer dizer, quando no entanto (E)ela pode e quer e diz. Entre o claro e o obscuro, o clarescuro, (e)Ela contém todo o espectro arcoirísiaco (e as demais cores que nem vemos?).

Não há culpa em não dizer quando o silêncio é sagrado, é promessa ou im-posição.

A grande culpa da literatura é então só, de novo e outra vez e ainda, romper o silêncio; expondo-se; ex-pondo-nus. 
DANIEL GLAYDSON RIBEIRO - pai de Anita e Tarsila, desde o final do inverno paulistano de dois mil e quinze. Doutor em Teoria Literária e Literatura Comparada na USP, por culpa da tese "Carnifágia malvarosa: as violações na Suma Poética de Jorge de Lima”, desde o outono de dois mil e dezesseis. De volta ao torrão quasi natal, neste inverno chuvoso que rápido o sertão esverdea. Armado até aos dentes, Ceará, contra os três poderes. 


\section{BIBLIOGRAFIA}

A BÍBLIA SAGRADA. Trad. por João Ferreira de Almeida. São Paulo: Sociedade Bíblica do Brasil, 1995.

BARTHES, Roland. Critique et vérité. Paris: Éditions du Seuil, 1966.

BRASIL. Constituição Federal, de 05.10.1988.

DE JAUCOURT, Louis. “Littérature”. In: DIDEROT; D’ALEMBERT. Encyclopédie, ou Dictionnaire Raisonné des Sciences, des Arts et des Métiers, par une société de gens de lettres. Paris: s/e, $175 . .$.

DE LIMA, Jorge. Poesia. v. 2. Rio de Janeiro: J. Aguilar; Brasília: INL, 1974.

Invenção de Orfeu. Rio de Janeiro: Livros de Portugal, 1952.

DERRIDA, Jacques. Donner la mort. Paris: Galilée, 1999.

FREUD, Sigmund. “O Estranho”. In: Obras psicológicas completas. v. XVII. Rio de Janeiro: Imago, 1976.

HUIDOBRO, Vicente. Altazor. Madrid: CIAP, 1931.

IANNI, Octavio. "Prece, sermão e diálogo”. In: Movimento, São Paulo, 16.02.1976.

LACAN, Jacques. Semináire XX: Encore. Paris: Éditions du Seuil, 1975.

LIBERTELLA, Héctor. La arquitectura del fantasma: Una autobiografía. Buenos Aires: Santiago Arcos, 2006

NASSAR, Raduan. Lavoura arcaica. Rio de Janeiro: José Olympio, 1975.

PERRIS, Antonios. "Carta de suicídio". hyperlink: http://www.diretoda redacao. com/noticia/a-morte-de-uma-vitima-do-capitalismo

"Suicide letter". hyperlink: http://aglimpseoflightintothedarkness.

wordpress.com/2012/05/25/desperate-suicide/

ROMANO DE SANT'ANNA, Affonso. “Grécia e o Sintagma”. hyperlink: http://www.musarara.com.br/grecia-e-o-sintagma 
